\title{
Kamu Kurumları Arasında Elektronik Belge Alışverişi ile İlgili Mevzuat ve Kamu Kurumlarında Yapılması Gerekenler
}

\author{
Legislation Related to Electronic Record Interchange Among \\ Public Institutions and Things to Do in Public Institutions
}

\author{
Mehmet Bilge Kağan ÖNAÇAN*
}

\begin{abstract}
Öz
Elektronik Imza Kanunu (EiK)'nun yürürlüğe girmesi ve mevzuatta yapılan güncellemeler ile birlikte elektronik ortamdaki bilgi ve belgelerin hukukî geçerlilik kazanması sağlanmış ve mevzuatın da zorlaması ile kamu kurumlarında belge yönetimine ilişkin iş süreçlerinin elektronik ortama aktarılması hızlanmıştır. Kurum içerisindeki belgelerin elektronik ortamda yönetilebilmesine yönelik olarak her bir kamu kurumu bir Elektronik Belge Yönetim Sistemi' (EBYS)'ni bünyesinde yapılandırmaya başlamıştır. Kurum içerisinde EBYS ile üretilen elektronik belgelerin (e-belge) kurumlar arasındaki alısverişine ilişkin hususların da Kalkınma Bakanlığı tarafından yürütülen e-Yazışma Projesi ve Bilgi Teknolojileri ve Illetişim Kurumu (BTK) tarafindan yürütülen Kayıtlı Elektronik Posta (KEP) Projesi ile çözümlenmesi planlanmaktadır. Bu çalışma ile anılan bu projeler ve bu projelerin kamu kurumlarına yüklediği sorumluluklar hakkında bilgilendirme yapmak ve farkındalık yaratmak hedeflenmiştir. Bu çalışmada literatür taraması yapılmış, proje ve ilgili mevzuattan doğrudan sorumlu personel ile görüşmeler gerçekleştirilmiş, konuyla ilgili kaynaklar ve özellikle mevzuat taranmış, değerlendirilmiş ve yorumlanmıştır. Kamu kurumlarının bünyelerinde ivedilikle TSE 13298 ve e-Yazışma Teknik Spesifikasyon Dokümanına uygun bir EBYS yapılandırarak KEP Hizmet Sağlayıııların (KEPHS) hizmete başlamasılyla bir KEP adresine sahip olmaları gerekmektedir.
\end{abstract}

Anahtar sözcükler: Kayıtlı Elektronik Posta, KEP, e-Belge, e-Yazışma

\section{Abstract}

Information and records in electronic environment have been valid in law by the enactment of Electronic Signature Act and the updates to legislation. With the enforcement of legislation, the transformation process of the business process related to record management from physical environment to electronic environment has been accelerated. In order to manage the records of public institution in electronic environment, every public institution started to establish an Electronic Record Management System (ERMS). The issues related to electronic record (e-record) interchange among public institutions are planned to solve by way of developing

* Y.Müh., Ankara Üniversitesi Siyasal Bilgiler Fakültesi İşletme Bölümü Doktora Öğrencisi. (mbko@yahoo.com)

1 Elektronik Belge Yönetim Sistemi (EBYS), kurumsal bilgi kaynakları olan belgelerin elektronik ortamda hazırlanması, onaylanması, paylaşılması, transferi, depolanması, kullanılması, kayıtlarının tutulması, arşivlenmesi yani kısaca belgenin yaşam çevrimi boyunca elektronik ortamda yönetilmesi için geliştirilmiş sistemdir (Önaçan, Medeni ve Özkanlı, 2012). 
e-Correspondence Project and Registered e-Mail (REM) Project. The aim of this study is to provide information and to raise the consciousness about the projects mentioned above and the responsibilities of public institutions. In this study; the literature and especially the legislation related to record management processes, electronic signature (e-signature) and REM have been reviewed and some interviews with responsible people related to projects and legislation have been done. It is necessary for public institutions to structure an ERMS which is appropriate to TSE 13298 and e-Correspondence Technical Specification Document and to buy a REM address after the REM Service Providers (REMSPs) start giving service.

Keywords: Registered e-Mail, REM, e-Record, e-Correspondence

\section{Giriş}

Teknolojinin sağladığı imkânlardan faydalanmak maksadıyla elektronik uygulamalar (e-uygulamalar) bugüne kadar kamu kurumlarının, özel sektörün ve vatandaşların karşılıklı güven duygusuna bağlı olarak kullanılmaktaydı (Uygun, 2012). 5070 sayılı Elektronik İmza Kanunu (EIK)'nun 23 Temmuz 2004 tarihinde yürürlüğe girmesiyle birlikte kamu kurumlarındaki belge yönetimine ilişkin olarak;

$\diamond \quad$ Elektronik ortamdaki bilgi ve belgelerin hukukî geçerlilik kazanması sağlanmış,

$\diamond$ Elektronik ortama aktarılan iş süreçleri artmış,

$\diamond$ İhtiyaç duyulan birkısım mevzuat değişikliklerigerçekleştirilmişve gerçekleştirilmeye devam etmekte,

$\diamond \quad$ Hâlihazırda kamu kurumlarında kullanılmakta olan e-uygulamalar da mevzuatın getirmiş olduğu standartlara uygun hale getirilmiş ve/veya getirilmeye devam etmektedir.

EiK'nın yayımlanması ile en yoğun çalışmaların belge yönetim süreçlerinin elektronik ortama aktarılması hususunda yapıldığı görülmektedir. Bu konuda önemli oranda mevzuat değişikliği gerçekleştirilmiş ya da gerçekleştirilmeye devam edilmektedir. Başbakanlık tarafından güncelleme çalışmaları devam etmekte olan ve yakın gelecekte yayımlanması planlanan Resmi Yazışmalarda Uygulanacak Usul ve Esaslar Hakkında Yönetmelik ile kamu kurum ve kuruluşlarının güvenli elektronik imza ile belge üreterek söz konusu belgelerin elektronik ortamda yönetimini sağlamaya yönelik mevzuattaki eksikliklerin giderileceği öngörülmektedir.

Elektronik ortamda belge yönetiminin gerçekleştirilmesinin sağlayacağı faydaların (Önaçan, Medeni ve Özkanlı, 2012, s.16-18) elde edilmesi için kamu kurum ve kuruluşlarının, kurum bünyesinde ivedilikle EBYS yapılandırmaları gerekmektedir. Kurum bünyesinde yapılandırılacak EBYS'lerin 2008/16 sayılı Başbakanlık Genelgesi gereği TSE 13298 no'lu Elektronik Belge Yönetimi Standardı́na ve e-Yazışma Projesi kapsamında geliştirilen kurallar setini tanımlayan "e-Yazışma Teknik Spesifikasyon Dokümanı"na uygun olması gerekmektedir. Anılan Genelgenin yayım tarihinden önce yapılandırılmış sistemlerin ise 16 Temmuz 2010 tarihi itibariyle TSE 13298 no'lu standarda uyumlu hale getirilmiş olması gerekmektedir.

2 "e-Yazışma Teknik Rehberi" olarak da isimlendirilmektedir. 
EBYS'ler, kurum içerisindeki belge yönetim süreçlerini elektronik ortama taşıyarak otomatikleştiren araçlardır. Kurum içinde EBYS ile hazırlanmış ve güvenli e-imza ile imzalanmış e-belgelerin kamu kurum ve kuruluşları arasında gönderilmesi ve alınmasına yönelik bir kısım mevzuat değiş̧ikliği yapılmasına ve standartların belirlenmesine de intiyaç duyulmaktadır. Bu kapsamda detayları ilerleyen bölümlerde sunulacak Kalkınma Bakanlığı tarafından yürütülen e-Yazışma Projesi ve BTK tarafından yürütülen Kayıtlı Elektronik Posta (KEP; Registered e-Mail: REM) Projesi başlatılmıştır.

Bu çalışmada özellikle kurumlar arasında belge alışverişi ile ilgili hususlara odaklanılarak sonraki bölümlerde e-Yazışma Projesi ile ilgili genel bilgiler verilmiş, KEP Projesi detayları ile anlatılmış ve kamu kurumlarında neler yapılması gerektiği ile ilgili değerlendirmeler sunulmuştur.

\section{e-Yazışma Projesi}

2001 yılında Avrupa Birliği (AB)'ne aday ülkeler için tasarlanan "e-Avrupa+" girişimine taraf olunmasıyla birlikte, Türkiye'de 2003/12 sayılı Başbakanlık Genelgesi ile Devlet Planlama Teşkilatı (DPT) Müsteşarlığı (yeni adıyla Kalkınma Bakanlığı) koordinasyonunda, vatandaşlara daha kaliteli ve hızlı kamu hizmeti sunabilmek amacıyla katılımcı, şeffaf, etkin ve basit iş süreçlerine sahip olmayı ilke edinmiş bir devlet yapısı oluşturacak koşulların hazırlanmasını hedefleyen "e-Dönüşüm Türkiye Projesi" başlatılmıştır. Bu kapsamda bilgi ve iletişim teknolojilerinden etkin olarak yararlanılması ve bilgi toplumuna ${ }^{4}$ dönüşümün gerçekleştirilmesine yönelik orta ve uzun vadeli strateji ve hedefleri belirlemek üzere, DPT tarafından, kamu kurum ve kuruluşlarına yükümlülükler yükleyen, Bilgi Toplumu Stratejisi (2006-2010) ve Bilgi Toplumu Stratejisi Eylem Planı (2006-2010) dokümanları Temmuz 2006'da yürürlüğe girmiştir ${ }^{5}$. Bilgi Toplumu Stratejisi (2006-2010)'nde, 2010 yılında kamuda bütün iç ve dış yazışmaların elektronik ortamda yapılması ${ }^{6}$ hedeflenmiş olmasına rağmen henüz gerçekleştirilememiş ancak çalışmalara devam edilmektedir.

Bilgi Toplumu Stratejisi eki Eylem Planı'nda yer verilen 73 no'lu “Ortak Hizmetlerin Oluşturulması" eylemi ile kamu kurum ve kuruluşlarında ortak olarak yürütülen bazı fonksiyonların merkezi olarak sunumu konusunda çalışmalar yapılması öngörülmüş ve Kalkınma Bakanlığı söz konusu eylemin sorumlusu olarak tespit edilmiştir (Kalkınma Bakanlığı, 2011, s.3).

3 Avrupa Birliği (AB)'nin 2010 yılında dünyadaki en rekabetçi ve dinamik bilgi tabanlı ekonomisi haline gelmesini amaçlayan Lizbon Stratejisi kapsamında e-Avrupa 2002 ve 2005 Eylem Planları hazırlanmıştır.

4 Bilgi toplumu; bireysel, örgütsel ve toplumsal düzeyde öğrenmenin yaşam biçimi olarak algılandığı, bilginin stratejik kaynak olarak değerlendirildiği, teknoloji kaynaklı değişim ve gelişimin hız kazandığı, küresel rekabetin yoğunlaştığı bir dönemi temsil etmektedir (Arslan, 2009, s.1506)

5 11.07.2006 tarihli ve 2006/38 sayılı Yüksek Planlama Kurulu Kararı'yla onaylanan Bilgi Toplumu Stratejisi ve Ek'i Eylem Planı 28.07.2006 tarihli ve 26242 sayılı Resmi Gazete'de yayımlanarak yürürlüğe girmiştir (Bilgi Toplumu Dairesi Başkanlığı, 2011).

6 Kamu Yönetiminde Modernizasyon- 2010 Yılı Hedefleri- Elektronik iletişim: Elektronik imza uygulamasının yaygınlaştırılması ve elektronik belge yönetimi standardizasyonu ile kurum içi ve kurumlar arası tüm yazışmalar, kademeli olarak, belirli güvenlik standartları dâhilinde elektronik kanallara taşınacaktır. Yasal sınırlamalar dışında, 2010 yılında kamuda tüm iç ve dış yazışmaların elektronik ortamda yapılması sağlanacaktır (Devlet Planlama Teşkilatı [DPT], 2006, s.35). 


\section{e-Yazışma Projesinin Amaç ve Kapsamı}

Kalkınma Bakanlığı tarafından Şubat 2011'de kamu kurum ve kuruluşları arasındaki resmi yazışmaların elektronik ortamda yürütülmesini sağlayacak ortak kurallar setinin geliştirilmesi ve bahsedilen kurallar setinin uygulanabilir olmasını sağlayacak yasal altyapının ortaya konmasını amaçlayan (Civelek ve Turan, 2010, s.17) e-Yazışma Projesi başlatılmış ve Eylül 2011'de tamamlanmıştır. Proje kapsamında; Cumhurbaşkanlığı, Başbakanlık, Adalet Bakanlığı, İçişleri Bakanlığı, Dışişleri Bakanlığı ve Kalkınma Bakanlığı'nı kapsayan ve geliştirilen çözümün test edildiği bir pilot uygulama yapılmıştır. Projeye Devlet Arşivleri Genel Müdürlüğü ve TÜBiTAK-BILGEM tarafından katkı sağlanmıştır (Kalkınma Bakanlığı, 2011, s.3).

e-Yazışma Projesi kapsamında; kamu kurum ve kuruluşları arasında iletilecek resmi yazışmalar ile bunların üstverilerini ve elektronik imzalarını taşıyacak paket yapısı belirlenmiş ve belgelerin kurumlar arasında güvenli şekilde iletilmesini sağlayacak şifreleme mekanizması ortaya konmuştur. Bu amaçla;

$\diamond$ Tüm bu mekanizmanın nasıl çalıştığını detaylı bir şekilde tanımlayan e-Yazışma Teknik Spesifikasyon Dokümanı hazırlanmış,

$\diamond \quad$ Bahse konu Rehber'de belirlenen teknik spesifikasyonu gerçekleyecek ve isteyen tüm kamu kurum ve kuruluşlarının kendi EBYS'lerine entegre edebilecekleri bir yazılım programlama arayüzü (API- Application Programming Interface) ${ }^{7}$ geliş̧tirilmiş,

$\diamond$ Hem tasarlanan sistem hem de geliştirilen API bir pilot uygulama kapsamında test edilmiş,

$\diamond$ Geliştirilen çözümü uygulamaya yönelik hukukî düzenleme önerileri ortaya konmuştur (Haber Depoları, 2012; e-Yazışma Projesi, 2012).

\section{Belgenin Imzalanması}

Teknolojinin gelişimine paralel olarak, süreçlerin elektronik ortama taşınmasıyla onay işlemlerinin elektronik ortamda gerçekleştirilmesi ihtiyacı ortaya çıkmış ve bunu sağlamak maksadıyla e-imza teknolojisi geliştirilmiştir. Güvenli e-imzanın elle atılan imza ile aynı ispat gücüne sahip olduğ ${ }^{8}$ ve bu şekilde oluş̧urulan elektronik verilerin hukuken geçerli olacağı hususlarını düzenleyen 5070 sayılı Eik ile e-imzanın resmi işlemlerde kullanılmasının yolu açılmıştır. EIK, e-imzanın hukukî ve teknik yönleri ile kullanımına ilişkin esasları düzenlemek yanında e-imzanın hukukî yapısını, elektronik sertifika (e-sertifika) hizmet sağlayıcılarının faaliyetlerini ve her alanda e-imzanın kullanımına ilişkin işlemleri kapsamaktadır (EiK, Madde 1 ve 2). Bahse konu kanunda e-imza, "başka bir elektronik veriye eklenen veya elektronik veriyle mantıksal bağlantısı bulunan ve kimlik doğrulama amacıyla kullanılan elektronik veri" şeklinde tanımlanmaktadır (EiK, Madde 3.b).

7 Yazılım programlama arayüzü (API- Application Programming Interface), bilgisayar programları tarafından yapılan istekleri desteklemeyi sağlayan fonksiyonların, prosedürlerin, metodların, sınıfların veya protokollerin kümesidir (Bail, 2012, s.1). Bir başka ifade ile yazılım programlama arayüzü, herhangi bir uygulamanın belli işlevlerini diğer uygulamaların da kullanabilmesi için oluşturulmuş bir modüldür (API Nedir?, 2012).

8 Elektronik İmza Kanunu (EIK)'nun 5inci Maddesine göre bazı istisnalar mevcuttur. Kanunların resmi şekle veya özel bir merasime tabi tuttuğu hukukî işlemler (emlak alım satımı, veraset ve intikal, evlenme gibi) ile teminat sözleşmeleri güvenli e-imza ile gerçekleştirilemez (Karabacak, 2009; Beder, 2005; Özler, 2007). 
e-Yazışma Projesi kapsamında tanımlanan ve kamu kurum ve kuruluşları arasındaki resmi yazışmaların tek bir formatta yapılmasını sağlayacak olan e-Yazışma Paketi ${ }^{9}$, üst yazının ekleriyle beraber imzalanmasına olanak sağlayan mekanizmayı da tanımlamaktadır (Kalkınma Bakanlığı, 2011, s.4-5). e-Yazışma Paketi ve belgelerin şifrelenmesi ile ilgili hususları detayları ile ortaya koyan e-Yazışma Teknik Spesifikasyon Dokümanı'nı gerçekleyen API, isteyen tüm kamu kurum ve kuruluşları tarafından kendi elektronik belge yönetim sistemlerine entegre edilerek kullanılabilmektedir.

\section{Belgenin Şifrelenmesi}

Belgelerin şifrelenmesi ile ilgili olarak, yetkili kuruluştan bir elektronik şifreleme sertifikasının temin edilmesi ve TÜBITAK Kamu Sertifikasyon Merkezi (Kamu SM) tarafından yayımlanan "Elektronik Belgeleri Açık Anahtar Altyapısı Kullanarak Güvenli İşleme Rehberi"ne uygun bir şifreleme mekanizması oluşturulması gerekmektedir (Kalkınma Bakanlığı, 2011, s.28).

EBYS, e-Yazışma Projesi ve KEP kabaca özetlenecek olursa; EBYS'ler, kurum içinde fiziksel ortamda gerçekleştirilen belge yönetim süreçlerinin elektronik ortamda gerçekleştirilmesini sağlayan araçlar; e-Yazışma Projesi, EBYS ile hazırlanan e-belgenin kurum dışına gönderilmesi için nasıl paketlenmesi gerektiğini tanımlayan standartlar; çalışmanın sonraki bölümünde detayları ile anlatılacak olan KEP ise fiziksel ortamda belgenin kurye/posta ile gönderilmesi sürecinin elektronik ortamda gerçekleştirilmesini sağlayan muadili olarak ifade edilebilir.

\section{KEP Projesi}

Türkiye'de kamu kurum ve kuruluşları arasında etkin olarak belge alış-verişinin sağlanabilmesi için altyapı oluşturmak maksadıyla gerçekleştirilmekte olan bir diğer proje de temeli ETSI TS 102640 numaralı standarda dayanan KEP projesidir.

KEP sistemine ilişkin dünyadaki ilk standart olan ETSI TS 102 640, Avrupa Telekomünikasyon Standartları Enstitüsü (ETSI) ${ }^{10}$ tarafından ilk önce 3 bölüm halinde taslak bir çalışma olarak yayımlanmış, daha sonra güncellenerek ve 5 bölüm olarak Ocak 2010 tarihinde yeniden yayımlanmıştır. Anılan Standardın bölümleri;

$\diamond$ KEP Sistem Mimarisi,

$\diamond \quad$ KEP'in İmzalanmış Delilleri İçin Veri Gereksinimleri ve Formatları,

$\diamond \quad$ KEP Yönetim Alanı İçin Bilgi Güvenliği Politika Gereksinimleri,

$\diamond \quad$ KEP Yönetim Alanı Değerlendirme Profilleri ve

$\checkmark$ KEP Yönetim Alanı Birlikte Çalışabilirlik Profilleridir (ETSI 102 640, 2012; Verion Teknoloji Grubu, 2012; Tanrıkulu, 2009, s.317).

9 e-Yazışma Paketi, bir belgeye ait tüm verinin tanımlanmış kurallara uygun şekilde tek bir elektronik dosya olarak ifade edilmiş biçimidir (Kalkınma Bakanlığı, 2011, s.4).

10 ETSI, Bilgi ve İletişim teknolojileri ile ilgili küresel-uygulanabilir standartlar üreten, Avrupa Birliği tarafından resmen Avrupa Standartlar Örgütü olarak kabul edilen ve dünya genelinde 62 ülkeden 700'den fazla örgütü bir araya getiren bir enstitüdür (AKCE, 2010). 
Türkiye'deki KEP Projesine benzer projelerin; İtalya, İsviçre, İsveç, Avusturya, Almanya, Belçika, Fransa ve İspanya gibi ülkelerde yasal düzenlemeleri de kapsayacak şekilde yapıldığı görülmektedir (Sevim, 2009; Ruggieri, 2010, s.314; Ünver, Kabasakal ve Günaydın, 2010, s.336-337; Kabasakal, 2012).

KEP'in Yasal Altyapısı

KEP sisteminin Türkiye'de yasal altyapısı;

- 14 Şubat 2011 tarihinde Resmi Gazetede yayımlanan, 13.01.2011 tarihli ve 6102 sayılı Yeni Türk Ticaret Kanunu (18'nci ${ }^{11}$ ve $1525^{\prime}$ nci $^{12}$ Maddeleri) ile

- BTK tarafından

$\diamond \quad 25$ Ağustos 2011 tarihinde yayımlanan

“Kayıtlı Elektronik Posta Sistemine İlişkin Usul ve Esaslar Hakkında Yönetmelik",

"Kayıtlı Elektronik Posta Sistemi İle İlgili Süreçlere ve Teknik Kriterlere İlişkin Tebliğ",

$\diamond 16$ Mayıs 2012 tarihinde yayımlanan "Kayıtlı Elektronik Posta Rehberi ve Kayıtlı Elektronik Posta Hesabı Adreslerine İlişkin Tebliğ" ve

$\diamond 06$ Haziran 2012 tarihinde yayımlanan “Kayıtlı Elektronik Posta Sisteminde Kullanılan İşlem Sertifikasına İlişskin Usul ve Esasların onaylanmasına ilişkin 2012DK-15/259 sayılı Kurul Kararı”ndan ibaret olan ikincil düzenlemelerle tamamlanmıştır (BTK, 2012).

\section{KEPNedir?}

KEP, elektronik iletilerin, gönderimi ve teslimatı da dâhil olmak üzere kullanımına ilişkin olarak hukukî delil sağlayan, Standart Elektronik Posta (SEP)'nın nitelikli şeklidir (BTK, 2011, s.1). Bir başka ifade ile KEP, farklı kişi ve kurumlar arasında elektronik ortamda hukuken geçerli ve güvenli bir şekilde bilgi ve belge gönderimi, teslimi ve saklanması hususlarını kapsayan, yasal olarak geçerli ve teknik olarak güvenli elektronik postadır (Samast, 2010, s.1).

KEP Sistemi, elektronik iletişim platformları aracılığıyla gerçekleşen, gönderildi ve alındı onayları da dâhil olmak üzere KEP iletilerinin tüm süreçlerine ilişkin olarak KEP delili oluşturulması, güvenli bir şekilde kimlik tespiti yapılması, KEP hesabı, KEP rehberi ve arşiv hizmetleri verilmesi gibi işlevlere sahip sistemdir (BTK, 2011, s.2). KEP sistemi, SMTP (Simple Mail Transfer Protocol- Basit Posta Aktarım Protokolü)'ye uygun olarak çalışan bir e-posta sistemidir. KEP sisteminde, hâlihazırda elektronik ortamda e-posta

11 MADDE 18- (3) Tacirler arasında, diğer tarafı temerrüde düşürmeye, sözleşmeyi feshe, sözleşmeden dönmeye ilişkin ihbarlar veya ihtarlar noter aracılığıyla, taahhütlü mektupla, telgrafla veya güvenli elektronik imza kullanılarak kayıtlı elektronik posta sistemi ile yapılır (Türk Ticaret Kanunu, 2011).

12 MADDE 1525- (1) Tarafların açıkça anlaşmaları ve 18 inci maddenin üçüncü fıkrası saklı kalmak şartıyla, ihbarlar, ihtarlar, itirazlar ve benzeri beyanlar; fatura, teyit mektubu, iştirak taahhütnamesi, toplantı çağrıları ve bu hüküm uyarınca yapılan elektronik gönderme ve elektronik saklama sözleşmesi, elektronik ortamda düzenlenebilir, yollanabilir, itiraza uğrayabilir ve kabul edilmişse hüküm ifade eder.

(2) Kayıtlı elektronik posta sistemine, bu sistemle yapılacak işlemler ile bunların sonuçlarına, kayıtlı posta adresine sahip gerçek kişilere, işletmelere ve şirketlere, kayıtlı elektronik posta hizmet sağlayıcılarının hak ve yükümlülüklerine, yetkilendirilmelerine ve denetlenmelerine ilişkin usul ve esaslar Bilgi Teknolojileri ve İletişim Kurumu tarafından bir yönetmelikle düzenlenir. Yönetmelik bu Kanunun yayımı tarihinden itibaren beş ay içinde yayımlanır (Türk Ticaret Kanunu, 2011). 
göndermek ve almak için kullanılan standart e-posta adresleri (abc.vyz@yahoo.com, abc.vyz @hotmail.com vb.) kullanılmamakta, hesap sahibinden alınan resmi belgelere dayanılarak kimliğin tasdik edilmesi sonucu, detayları ileride verilecek olan, yetkili KEPHS tarafından tahsis edilen kayıtlı e-posta adresleri ${ }^{13}$ (Örneğin; adi.soyadi.sayi@hsY. kep.tr) kullanılmaktadır. Hâlihazırda elektronik ortamda e-posta göndermek ve almak üzere kullanılmakta olan yahoo ve hotmail benzeri e-posta sistemlerinin yasal olarak geçerliliği yoktur ve teknik olarak güvenli kabul edilmemektedir. Buna ek olarak bu tür sistemlerde iletimin kesin olarak sağlandığının bir garantisi olmadığı gibi gönderen göndermediğini ve alan da almadığını inkâr edebilmektedir.

\section{KEP'in Yararları}

KEP Sisteminin sağladığı yararları aşağıdaki şekilde sıralamak mümkündür (BTK, 2012):

$\diamond$ e-Belgenin orijininin (işlemi yapan) belirlenmesi,

$\diamond$ e-Belgenin bütünlüğünün (belgede değişiklik yapılıp yapılmadığının) korunması,

$\diamond$ e-Belge üzerinde yapılan işlem tarihi ve saatinin belirlenmesi,

$\diamond$ e-İmza ve zaman damgası kullanılarak, bir e-belgenin iletildiğinin garanti altına alınması,

$\diamond$ İşlemi yapanın işlemi inkâr edememesi (işlemi yapan kişi belgeyi kendisine ait güvenli e-imza ile imzalar) (gönderen göndermediğini ya da gönderdiğini, alan da almadığını inkâr edemez),

$\diamond$ İletişimin gizliliği prensiplerine uygun olarak elektronik ortamda güvenli haberleşme,

$\diamond$ e-Belgelerin güvenli bir ortamda saklanması,

$\diamond$ Kâğıt, postalama, arşivleme ve işlem maliyetlerinin düşürülmesi ve zaman kayıplarının azaltılmasıyla, önemli oranda tasarruf (Samast, 2012),

$\checkmark$ Resmi ve ticari işlemlerin hızlı ve verimli yapılması (Samast, 2012).

KEP sistemi kullanılarak verilebilecek hizmetlerden bazıları da (BTK,2012);

$\diamond$ Kamu kurum ve kuruluşlarının aralarında elektronik ortamda resmi yazışma yapmaları,

$\diamond$ Kamu kurum ve kuruluşlarının özel sektör ve vatandaşla elektronik ortamda yazışmaları,

$\diamond$ Vatandaşların ve özel sektörün elektronik ortamdaki her türlü bilgi ve belge paylaşımı,

$\diamond$ E-Tebliğ, e-fatura, e-bildirge, e-sözleşme, e-başvuru, e-dilekçe gibi uygulamalardır.

13 KEP adresleri, Kayıtlı Elektronik Posta Rehberi ve Kayıtlı Elektronik Posta Hesabı Adreslerine İlişkin Tebliğ ile düzenlenmektedir. 


\section{KEPHS Nedir?}

KEP Sistemi; yasalar ve ilgili mevzuata uygun ve başta ETSI TS 102640 standardı olmak üzere uluslararası KEP, bilgi güvenliği, ortak kriterler, iş sürekliliği ve olay yönetimi, Web erişilebilirlik girişim yönergesi (engelli kişilerin KEP'ten yararlanabilmesi için) standartlarına uyumlu olarak altyapısını kurmuş ve BTK'dan yetki almış KEPHS'leri tarafından işletilecektir (Verion Teknoloji Grubu, 2012).

KEP sisteminin altyapısı BTK koordinesinde PTT tarafından oluşturulmaktadır. Türkiye'de, altyapı çalışmalarının tamamlanmasını müteakip PTT ve KEP sistemi kuran özel firmalar ${ }^{14} 01$ Mayıs 2012 tarihinden itibaren BTK'ya başvurarak KEPHS yetkisi alabilecekler ve 01 Temmuz 2012 tarihinden itibaren de KEP hizmeti verebileceklerdir.

KEPHS'nin, KEP sisteminde çok önemli işlevi olan güvenli e-imza ve zaman damgası işlemleri için bağımsız/harici bir Elektronik Sertifika Hizmet Sağlayıcısı ${ }^{15}$ (ESHS)'ndan hizmet alması gerekmektedir. KEPHS'nin güvenli e-imza sertifikasını ve zaman damgasını kendi içinde üretmesi güvenilirlik açısından uygun görülmemektedir. Aynı nedenle, ESHS'lerin KEP hizmeti vermeleri de uygun görülmemektedir. Bu açıdan bakıldığında, ESHS'lerin KEPHS, KEPHS'lerin da ESHS olmasının güvenilir üçüncü taraf konseptine aykırı olması sebebiyle uygun olmadığı değerlendirilmektedir (Verion Teknoloji Grubu, 2012). Nitekim KEP Yönetmelik'i gereği ESHS olarak faaliyet gösterenler KEPHS olamamaktadırlar ${ }^{16}$. Hâlihazırdaki mevzuatta, kamu kurum ve kuruluşlarının KEPHS hizmetini, PTT'den veya özel bir firmadan temin etmesine yönelik bir husus yer almadığından, hizmet PTT veya özel bir firmadan temin ve tedarik edilebilecektir.

KEPHS'ler, KEP hesabı sahibi ile aksi bir anlaşma yapılmadığı sürece, gönderilerin içeriğinin kopyasını tutamaz, sadece iletim işlemini gerçekleştirir ve bu işlemlerle ilgili delilleri üretip en az 20 yıl süre ile saklarlar. Ayrıca KEPHS'ler, KEP hesap sahipleri için 100 MB depolama alanı sunmak, 10 MB'a kadar büyüklükteki iletilerin iletimini yapmak, depolama alanının dolması durumunda KEP hesap sahibinin ileti almasını sağlamak (ileti gönderilmesini engelleyebilir) zorundadırlar.

KEPHS'ler, KEP sistemi içerisinde bir elektronik iletinin gönderilmesi ve alınması dışında elektronik belgelerin saklanması, güvenli iletişim ve elektronik ortamda güvenilir üçüncü taraf hizmetleri gibi katma değerli hizmetler sunabilir ve sunduğu hizmetlere ilişkin ücretleri belirleyebilirler ${ }^{17}$.

14 Kamu kurumları, meslek örgütleri, Sivil Toplum Kuruluşları A.Ş. olarak KEPHS olmak üzere başvuru yapabileceklerdir (Samast, 2012, s.15).

155070 sayılı Elektronik İmza Kanununa göre; ESHS, elektronik sertifika, zaman damgası ve elektronik imzalarla ilgili hizmetleri sağlayan kamu kurum ve kuruluşları ile gerçek veya özel hukuk tüzel kişilerdir (Madde 8).

16 ESHS olarak veya 5/11/2008 tarihli ve 5809 sayılı Elektronik Haberleşme Kanunu kapsamında işletmeci olarak faaliyet gösterenler KEPHS olmak için başvuruda bulunamaz (BTK, 2011, Madde 6- (4)).

17 BTK, KEPHS ücretlerine alt ve üst sınır getirebilmektedir (BTK, 2011, Madde 19- (1)). 


\section{KEP Hesabı Sahiplerinin Sorumlulukları}

01 Temmuz 2012 tarihinden itibaren gerçek veya tüzel kişiler KEPHS'ye başvurarak KEP hesabı alabileceklerdir. Mevzuata göre, KEP sisteminde "gönderici" gerçek veya tüzel kişilerin, 5070 sayılı Elektronik İmza Kanunu ve ilgili mevzuat çerçevesinde Nitelikli Elektronik Sertifika (NES) sahibi olması, KEP adreslerinin kullanıma açılmasını güvenli e-imza ile onaylaması ve KEP gönderilerinde güvenli e-imza kullanması zorunludur. "Alıcıların güvenli e-imza sahibi olma zorunluluğu yoktur; elle atılan ıslak imzalarıyla veya güvenli e-imza ile KEP hesaplarının kullanıma açılmasını onaylayabilirler (Verion Teknoloji Grubu, 2012).

KEP hesabı sahibi gerçek veya tüzel kişinin önemle göz önünde bulundurması gereken bir husus, mücbir sebep ${ }^{18}$ hâlleri dışında KEP hesabına erişilmemesi durumunda o işgünü içinde gelen iletinin ertesi işgünü hesap sahibine ulaştığının ve okunduğunun kabul edilmesidir ${ }^{19}$ ki bu KEP hesabı sahibinin düzenli olarak KEP hesabına erişerek gelen iletileri kontrol etmesini gerektirmektedir.

\section{Kamu Kurumlarında Yapılması Gerekenler}

Ülkemizde 5070 sayılı EiK'nın e-belgeyi yasal hale getirmesinin ardından Türk Ticaret Kanunu'nun KEP ile ilgili maddeleri de e-belgenin elektronik ortamda iletimini yasal olarak geçerli hale getirmiştir. Bu gelişmeler paralelinde özellikle son yıllarda mevzuatta yapılan güncellemeler sonucunda yakın gelecekte belge yönetimi süreçlerinin büyük oranda elektronik ortamda gerçekleşeceği değerlendirilmektedir. Bu kapsamda kamu kurumlarında yakın ve orta vadede yapılması gerekenler genel hatlarıyla aşağıda özetlenmiştir:

Öncelikle, EBYS kullanan kamu kurumlarında -eğer gerçekleştirilmemişse- mevcut EBYS'nin TSE 13298 standardı ile e-Yazışma Teknik Spesifikasyon Dokümanı'na uygun ve güvenli e-imza ile entegre edilmiş hale getirilmesi; EBYS kullanmayan kamu kurumlarında ise bahsedilen özelliklere sahip, kurum ihtiyaçlarına ve iş süreçlerine cevap veren, tercihen yakın gelecekte yayımlanacağı öngörülen taslak Resmi Yazışmalarda Uygulanacak Usul ve Esaslar Hakkında Yönetmelik'e uygun bir EBYS yapılandırılması gerekmektedir.

Kurum personeli için, dokümanların elektronik ortamda imzalanmasında kullanılacak NES'lerin tedarikine ilişkin bir politika belirlenerek; hangi personel için NES temin edileceğine karar verilmelidir. Bu kapsamda kurum içinde kullanılmakta olan hangi uygulamalarda NES kullanılacağı tespit edilmeli, uygulamaya özel olarak da nerelerde e-imzalama ve zaman damgalaması yapılacağı kararlaştırılmalıdır. Kamu SM'den temin edilecek e-imzalama API'sının, belirlenmiş olan bu uygulamalara entegre edilmesi sağlanmalıdır.

18 Mücbir sebep (act of god), insan iradesi ve gücü ile önlenemeyecek bir olayı ifade eder. Mücbir sebep hâlleri, 213 sayılı Vergi Usul Kanunu"nun 13"üncü maddesi ile düzenlemiştir.

19 Kayıtlı e-Posta Yönetmeliği md. 12/f.2. 
Yürüttükleri görevleri açısından özel niteliği haizTürk Silahlı Kuvvetleri (TSK), Emniyet Genel Müdürlüğü, MiT Müsteşarlığı, Jandarma Genel K.lığı, Sahil Güvenlik K.ığı, Dışişleri Bakanlığı ve Bilgi Teknolojileri ve İletişim Kurumu ${ }^{20}$ gibi istisnai kurumlar21, gizlilik, güvenlik, kurumsal kontrol ihtiyacı, teknik altyapı, personel yeterliliği ve maliyet etkinlik gibi hususları göz önünde bulundurarak çalışanları için NES teminini Kamu SM'den mi yoksa kendi bünyelerinde yapılandıracakları ESHS'lerden mi temin edeceklerine karar vermelidirler (Önaçan ve Medeni, 2012).

KEPHS'lerden temin edilecek hesapların hangi birim tarafından nasıl tedarik edileceğine karar verilmeli ve gerekli bütçe planlanmalıdır.

Kamu kurumları tarafından, kuruma e-belgenin gireceği birimlerde (Genel Evrak vb.) ilgili personel için bir KEPHS'den KEP hesabı temin edilmesinin ve kuruma gelen e-belgelerin KEP sisteminden alınarak (bu aşamada e-Yazışma Teknik Spesifikasyon Dokümanı'na uygun şekilde oluşturularak bir paket haline getirilmiş olan e-belgelerin, e-Yazışma Projesi kapsamında geliştirilmiş olan API'nın kullanılması suretiyle açılmasına ihtiyaç duyulacağı değerlendirilmektedir) imza doğrulama işleminin yapılmasını müteakip;

$\diamond$ EBYS'si olan kurumlar için EBYS'ye aktarılarak elektronik ortamda havalesinin ve işlemlerinin yapılmasının,

$\diamond \quad$ Bünyesinde henüz EBYS yapılandırmamış kurumlar için, (EiK gereği kuruma gelen e-belgelere işlem yapmak zorunluluğu olduğundan) kâğıt çıktısının alınmasının ve üzerine "BELGENIN ASLI ELEKTRONIK IMZALIDIR" ibaresi vurulmak ${ }^{22}$ suretiyle geleneksel yöntemlerle fiziksel ortamda havalesinin ve işlemlerinin yapılmasının uygun hal tarzı olacağı değerlendirilmektedir ${ }^{23}$.

Kurumdaki mevcut EBYS'de hazırlanan ve güvenli e-imza ile imzalanan e-belgenin bir başka kuruma gönderilmesi için ise e-belgenin kurumdan gönderileceği birimlerde (Genel Evrak vb.) ilgili personel için Kamu SM'den güvenli e-imza ve bir KEPHS'den KEP hesabı temin edilmelidir. Kurum dışına gönderilecek e-belge, güvenli e-imza ve KEP hesabı temin edilmiş personel tarafından KEP sistemi kullanılmak suretiyle hazırlanacak ve güvenli e-imza ile imzalanacak e-postaya eklenerek ilgili adreslere gönderilmeli, gönderinin "teslim edildi" ve "okundu" geri bildirimleri takip edilmelidir (Kabasakal, 2012; Alkan, 2008).

Kuruma elektronik ortamda gelen belgeler ile kurumdan elektronik ortamda gönderilecek belgelere nasıl işlem yapılacağına ilişkin esasların belirlenerek personele duyurulması göz ardı edilmemelidir.

2025 Temmuz 2006 tarihli ve 26239 sayılı Resmi Gazete'de yayımlanan 2006/20 sayılı Başbakanlık Genelgesi ile “Kamu Sertifikasyon Merkezi" konulu 2004/21 sayılı Genelge'nin altıncı fıkrasında belirtilen istisnai kurumlara "BTK" da eklenmiştir.

21 Bahsi geçen istisnai kurumlar 2004/21 sayılı Başbakanlık Genelgesi gereği ESHS sistemlerini kendi bünyelerinde oluşturabileceklerdir.

22 Resmi Yazışmalarda Uygulanacak Usul ve Esaslar Hakkında Yönetmelik Taslağı Madde 27- (2).

23 Kurum dışına e-belge gönderilmediği sürece Genel Evrak vb. birimlerdeki personel için güvenli e-imza alınmasına gerek olmadığı değerlendirilmektedir. 
Hem kurum içinde, hem de kurumlar arasında e-belgenin (özellikle Tasnif Dışı gizlilik derecesinin üzerindeki belgelerin) güvenli olarak gönderilip alınabilmesi ayrıca kurum bünyesinde e-belgenin güvenli olarak saklanabilmesi için şifrelemeye ihtiyaç duyulacağı değerlendirilmektedir. e-Belgenin şifrelenmesi için de bir şifreleme sertifikasına ihtiyaç duyulmaktadır. Hem idari hem de teknik sebeplerle şifreleme sertifikasının, e-imza maksatlı kullanılan NES'den farklı olması gerekmektedir. Bu maksatla kurum bünyesinde nasıl bir şifreleme mekanizması oluşturulacağı kararlaştırılmalıdır.

\section{Sonuç}

Teknolojinin sağladığı imkânlarla ve mevzuatta gerçekleştirilen güncellemelerle belge yönetimi süreçleri elektronik ortama aktarılmaya devam etmektedir. Elektronik ortamda gerçekleştirilen belge yönetimi süreçlerinin; cari işleri azaltarak süreci hızlandırmak, güvenliği artırmak, maliyeti düşürmek, personel motivasyonunu ve verimliliği artırmak ve organizasyon içinde bilginin yönetilmesine katkı sağlamak gibi önemli faydalar sağlayacağı değerlendirilmektedir. KEP sistemi de elektronik ortamda belge yönetimi sürecinde kurumlar arasında belgenin alış verişini kolaylaştırarak ve hukuksal olarak geçerli hale getirerek bu sürece önemli katkılar sağlayacaktır.

Ticari ve özel her türlü belgenin süratli, ekonomik ve güvenli olarak ticari kuruluşlar, şahıslar ve kamu kurumları arasında alış verişine imkân sağlayacak KEP sisteminin hizmet vermeye başlamasıyla öncelikle finans ve telekomünikasyon sektörü ile e-belge altyapısını oluşturmuş kamu kurumlarında kullanılacağı, süreçlerin olgunlaşmaya ve kültürün yerleşmeye başlamasıyla tüm sektörlerde kullanımın yaygınlaşacağı değerlendirilmektedir.

\section{Kaynakça}

AKCE (2010). Electronic Signatures and ETSI Standards. Republic of Albania, National Authority for Electronic Certification. 06 Ekim 2012 tarihinde http://www.akce.gov.al/documents/etsi_ standards_english.pdf adresinden erişildi.

Alkan, M. (2008). Kayıtlı Elektronik Posta (KEP) Sistemi. e-Dönüşüm Türkiye İcra Kurulu'nun 26 Aralık 2008 tarihindeyapılan 26'ncı toplantısı. 08 Ekim 2012 tarihinde http://www.bilgitoplumu.gov.tr/ Documents/1/Icra_Kurulu/081226_IK26.ToplantisiToplantisiKayitliElektronikPostaProjesiBTK. pdf adresinden erişildi.

API Nedir? (2012). 18 Kasım 2012 tarihinde www.tekniksorular.com adresinden erişildi.

Arslan, R. (2009, 24-27 Eylül). Bilgi toplumuna geçiş sürecinde bilginin artan ekonomik değeri ve işletmeler üzerindeki etkileri. Uluslararası Davraz Kongresi'nde sunulan bildiri. 19 Haziran 2012 tarihinde http://idc.sdu.edu.tr/tammetinler/yonetim/yonetim25.pdf adresinden erişildi.

Bail, S. (2012). Application Program Interface (API) A path to seamless software integration. 14 Kasım 2012 tarihinde http://www.cabinetng.com/media/API.pdf adresinden erişildi.

Beder, F. (2005). Elektronik belge yönetim sistemi ve TCMB örneği. Uzmanlık Yeterlilik Tezi, TC Merkez Bankası, Ankara. 
Bilgi Teknolojileri ve İletişim Kurumu. (2011, 25 Ağustos). Kayıtlı Elektronik Posta Sistemine İlişkin Usul ve Esaslar Hakkında Yönetmelik.

Bilgi Teknolojileri ve İletişim Kurumu. (2012). 12 Ocak 2012 tarihinde www.tk.gov.tr adresinden erişildi.

Bilgi Toplumu Dairesi Başkanlığı. (2011). 30 Mart 2011 tarihinde http://www.bilgitoplumu.gov.tr/ Portal.aspx?value=UE9SVEFM UQ9MTYZIBBR0VWRVJTSU9OPS0xJk1PREU9UFVCTEITSEVEX1 ZFUINJT04=adresinden erişildi.

Civelek, D. Y. ve Turan, H. K. (2010). Kurumlar arası e-Yazışma çalışma raporu, Ankara: DPT Bilgi Toplumu Dairesi Başkanlığı.

Devlet Planlama Teşkilatı. (2006). Bilgi Toplumu Stratejisi (2006-2010). Ankara: Devlet Planlama Teşkilatı.

e-Yazışma Projesi. (2012). 08 Mayıs 2012 tarihinde http://www.e-yazisma.gov.tr adresinden erişildi.

Elektronik İmza Kanunu. (2004, 23 Temmuz). 5070 sayılı Elektronik İmza Kanunu.

ETSI TS 102 640. (2012). Electronic Signatures and Infrastructures (ESI); Registered Electronic Mail (REM). 06 Ekim 2012 tarihinde http://webapp.etsi.org/workprogram/Frame_ WorkltemList.asp?qSORT=HIGHVERSION\&qETSI_ALL=\&SearchPage $=$ TRUE\&qETSI_ NUMBER $=102+640 \& q I N C L U D E \_S U B \_T B=T r u e \& q I N C L U D E \_M O V E D \_O N=\& q S T O P$ _ $\mathrm{FLG}=\& q K E Y W O R D \_B O O L E A N=\& q S T O P P I N G \_O U T D A T E D=\&$ butSimple=Search\&includeNonActiv eTB=FALSE\&includeSubProjectCode=\&qREPORT_TYPE=SUMMARY adresinden erişildi.

Haber Depoları. (2012). 16 Ocak 2012 tarihinde www.haberdisk.com adresinden erişildi.

Kalkınma Bakanlığı. (2011). e-Yazışma Projesi teknik spesifikasyon dokümanı. Ankara: Kalkınma Bakanlığı.

Kabasakal, D. (2012, 1-5 Haziran). Kayıtlı e-Posta (KEP). EBYS Semineri'nde sunulan bildiri, Ankara:TODAiE.

Karabacak, B. (2009). Türkiye'de bilişim güvenliği ile ilgili yasal altyapıların analizi. 03 Ocak 2012 tarihinde www.bilgiguvenligi.gov.tr adresinden erişildi.

Önaçan, M.B.K. ve Medeni, T.D. (2012). Elektronik imza nedir, neden gereklidir, ihtiyacı nasıl karşılanmalıdır?. Türk Idare Dergisi, 474(Haziran), 171-194.

Önaçan, M.B.K., Medeni, T.D. ve Özkanlı, Ö. (2012). Elektronik Belge Yönetim Sistemi (EBYS)'nin faydaları ve kurum bünyesinde EBYS yapılandırmaya yönelik bir yol haritası. Sayıştay Dergisi, 85 (Nisan-Haziran), 1-26.

Özler, İ. (2007). Bilgi güvenliği ve elektronik imza kavramları, ekonomik boyutlarının incelenmesi ve elektronik imza uygulamaları. Yayınlanmamış yüksek lisans tezi, Dicle Üniversitesi, Diyarbakır.

Ruggieri, F. (2010). Registered e-mail (REM) - reliable e-mail for everybody. Datenschutz und Datensicherheit - DuD, 34(5), 314-317.

Samast, Y. (2010, 10-12 Şubat). Kayıtlı Elektronik Posta (KEP). Akademik Bilişim 2010'da sunulan bildiri, Muğla. 07 Şubat 2012 tarihinde www.ab.org.tr/ab10/bildiri/202.pdf adresinden erişildi.

Samast, Y. (2012, 01-02 Mart). Kayıtlı elektronik posta-yasal ve güvenli e-posta. III.Bilgi Teknolojileri Yönetişim ve Denetim Konferansı'nda sunulan bildiri, İstanbul. 16 Nisan 2012 tarihinde http:// www.btyd.org/tr/3sunum/ysamast.pdf adresinden erişildi. 
Sevim, T. (2009). Kayıtlı Elektronik Posta (KEP) sistemi. Mobil Devlet 2009 Yılı Sunumları, 06 Ekim 2012 tarihinde http://www.mdevlet.org adresinden erişildi.

Tanrıkulu, C. (2009). Türk ve Avusturya hukukunda elektronik tebligat. TBB Dergisi, 85, 315-331.

Türk Ticaret Kanunu. (2011, 13 Ocak). 6102 sayılı Türk Ticaret Kanunu.

Uygun, N. (2012). Kayıtlı Elektronik Posta (KEP) nedir ve neler sağlar?. 19 Mayıs 2012 tarihinde http://www.cozumpark.com adresinden erişildi.

Ünver, M., Kabasakal, D. ve Günaydın Y. (2010, 06-08 Mayıs). Kayıtlı elektronik posta sistemi ve hizmetleri. 4. Uluslararası Bilgi Güvenliği ve Kriptoloji Konferansı'nda sunulan bildiri. 19 Kasım 2012 tarihinde http://www.iscturkey.org/iscold/2010.html adresinden erişildi.

Verion Teknoloji Grubu. (2012). 12 Ocak 2012 tarihinde http://www.verion.com.tr adresinden erişildi. 